\title{
Removal of pharmaceutically active compounds from aqueous solutions onto several macroporous resins: $\mathrm{A}$ comparative study
}

\author{
Özçelik G, Kurtulbaş E, Bilgin M and Şahin S* \\ Istanbul University-Cerrahpaşa, Engineering Faculty, Department of Chemical Engineering, 34320, Avcılar, Istanbul, Turkey
}

\begin{abstract}
Within the scope of this study, a comprehensive research has been conducted to develop an effective procedure for the treatment of pharmaceutically active compounds (FAC) found in wastewater. Carmabazine (CAM) and ibuprofen (IBU) have been selected as the model FAC to investigate the adsorption performance of various macroporous resins (XAD 2, 4, 7 and 16). The adsorption removal was found to be between 87 and $99 \%$ under the optimum conditions (500 mg of adsorbent for the adsorption of $30 \mathrm{mg} \mathrm{L-1} \mathrm{CAM} \mathrm{and} \mathrm{IBU} \mathrm{solutions} \mathrm{at} 150 \mathrm{rpm}$ mixing speed of shaking bath). Equilibrium (Langmuir and Freundlich isotherms) and kinetic (pseudo-first order and pseudo-second order) models have been applied for analysis and representation of data.
\end{abstract}

\section{Introduction}

Various changes and degradation have been happening on the Earth by the increase in the living population. The unconscious and uncontrolled use of drugs produced for the diagnosis and treatment of diseases is a major threat to water resources. As a result of metabolic activities in the body, medical drugs are discharged through urine without disintegration or degradation [1,2]. In this way, the active substances pollute the water resources by reaching the sewers and even the treatment plants. Firstly, the determination of chlorophilic acid and active metabolites in the effluent of the wastewater treatment plant showed how big the problem was in the USA in the 1970s [3]. The drug active substances present in the effluent discharge adversely affect the hormonal system. The most well-known effect of drug residues involved in nature is the increase in resistant pathogenic microorganisms [4].

Ibuprofen (IBU) is a non-steroidal anti-inflammatory drug, which is one of the most preferred active substances for its analgesic, antipyretic and anti-inflammatory effects [5]. Continuous accumulation of this substance can cause serious environmental problems. On the other hand, carbamazepine (CAM) is used in the treatment of posttraumatic stress, drug and alcohol withdrawal, restless leg syndrome and sugar-free diabetes [6]. Adsorption/desorption processes are one of the methods used to separate substances, such as pharmaceuticals, in a small amount, from a complex medium containing a wide variety of chemical components. Solvent extraction might be a choice to recover pollutants from such media, but its selectivity is relatively low. Further purification might be required, which results in extra costs and waste generation. Ecological issues caused by solvents have forced the development of easier, more selective, more effective and greener technologies. Adsorption is a separation method with low cost and simplicity in regeneration. It is also a simple method in terms of design, operation and scaling compared to alternative methods. Additionally, it prevents the use of toxic solvents, and minimizes degradation [7]. Several kinds of adsorbents have been used in the separation of pharmaceuticals with high environmental risks [8] such as CAM and
IBU from aqueous media by adsorption-desorption processes. Natural clay [9], activated carbon [10], porous silica $[8,11,12]$, natural sandy sediment [13]. Metal organic frameworks with porous structure have been also popular for the removal of the related PACs from wastewater [14]. In this study, 4 different macroporous resins (XAD 2, 4, 7 and 16) have been used in the removal of CAM and IBU from their aqueous solutions.

\section{Materials and methods}

\section{Chemical materials}

Macroporous resins [15], CAM, IBU, sodium chloride $(\mathrm{NaCl})$, hydrochloric acid $(\mathrm{HCl})$, sodium hydroxide $(\mathrm{NaOH})$ were from Sigma Aldrich Co. (St. Louis, MO, USA).

\section{Adsorption of CAM and IBU}

Stock solutions at $30 \mathrm{mg} \mathrm{L}-1$ were adjusted by diluting certain amount of PACs by water. PAC concentrations were determined spectrophotometrically (Perkin Elmer Lambda 35 UV/Visible Spectrophotometer) at 285 (CAM) [16] and 225 (IBU) [17] nm, respectively. The yield of the PAC removal was stated as adsorption capacity $\left(\mathrm{q}_{\mathrm{e}}, \mathrm{mg} \mathrm{g}^{-1}\right)$ :

$$
q_{e}=\frac{\left(C_{i}-C_{e}\right) \times V}{m}
$$

*Correspondence to: Selin Şahin, Istanbul University-Cerrahpaşa, Engineering Faculty, Department of Chemical Engineering, 34320, Avc1lar, Istanbul, Turkey, Tel: +90-212-4737070 (17679), Fax: +90-212-4737180, E-mail: selins@istanbul.edu.tr

Key words: pharmaceutically active compounds, wastewater, ionic strength, kinetics, thermodynamics

Received: September 20, 2019; Accepted: October 06, 2019; Published: October 11,2019 
Where $\mathrm{V}(\mathrm{L})$ donates the CAM and IBU solution volume, and $\mathrm{m}(\mathrm{g})$ is the adsorbent dosage. Initial concentration is represented by $\mathrm{C}_{\mathrm{i}}(\mathrm{mg}$ $\left.\mathrm{L}^{-1}\right)$, while the concentration at equilibrium is $\mathrm{C}_{\mathrm{e}}\left(\mathrm{mg} \mathrm{L}^{-1}\right)$.

\section{Results and discussions}

\section{Determination of equilibrium time}

Figures $1 \mathrm{a}$ and $1 \mathrm{~b}$ show the equilibrium time of the systems in terms of adsorption capacity of CAM and IBU, respectively. $25 \mathrm{~mL}$ of 30 $\mathrm{mg} \mathrm{L}^{-1} \mathrm{CAM}$ and IBU solutions were added into $500 \mathrm{mg}$ adsorbents in determining the equilibrium time. The samples were placed in a shaker water bath at a stirring speed of $150 \mathrm{rpm}$ at $298 \mathrm{~K}$. Regarding CAM removal, XAD 2 and 4 resins reached equilibrium in 240 minutes, XAD 7 resin in 45 minutes and XAD 16 resin in 45 minutes (Figure 1a). Since $\mathrm{XAD} 2$ resin has a much lower adsorption capacity than the other three resins, studies have continued with XAD 4, 7 and 16 . When the IBU is considered, equilibrium was reached at $270 \mathrm{~min}$ for XAD 2, $240 \mathrm{~min}$ for XAD 4, 120 min for XAD 7 resin and finally 90 min for XAD 16 resin (Figure $1 \mathrm{~b}$ ).

\section{Kinetic studies}

Pseudo-first order and pseudo-second order kinetic models were applied to the experimental data for the removal of CAM and IBU from its aqueous media, respectively. Pseudo-first order kinetic model is as follows [18]:

$$
\ln \left(q_{e}-q_{t}\right)=\ln q_{e}-k_{1}^{t}
$$

$\mathrm{q}_{\mathrm{t}}$ : Adsorption capacity at any time (mg g-adsorbent $\left.{ }^{-1}\right)$

$\mathrm{k}_{1}$ : Rate constant of pseudo-first order model $\left(\mathrm{min}^{-1}\right)$.

Pseudo-second order kinetic model is as follows [19]:

$$
\frac{t}{q_{t}}=\frac{1}{k_{2} q_{e}^{2}}+\frac{t}{q_{e}}
$$

$\mathrm{k}_{2}$ : Rate constant of pseudo-second order model $\left(\mathrm{g} \mathrm{mg}^{-1} \mathrm{~min}^{-1}\right)$

Table 1 demonstrates the the kinetic parameters with the determination coefficients $\left(\mathrm{R}^{2}\right)$. The results for the present system show that the data are compatible with both models. Relatively high $\mathrm{R}^{2}(>0.98)$ for the pseudo-second order kinetic equation is a sign of chemisorption [19].

\section{Equilibrium studies}

Adsorption isotherms are of great significance to the design purposes of an adsorption process, since these equations describe the interaction between the adsorbent and adsorbed materials. Table 2 presents the isotherm models with the equations used in this study.

Table 3 displays the selected isotherm parameters for CAM and IBU adsorptions onto the resins, respectively. The compatibility of the

a
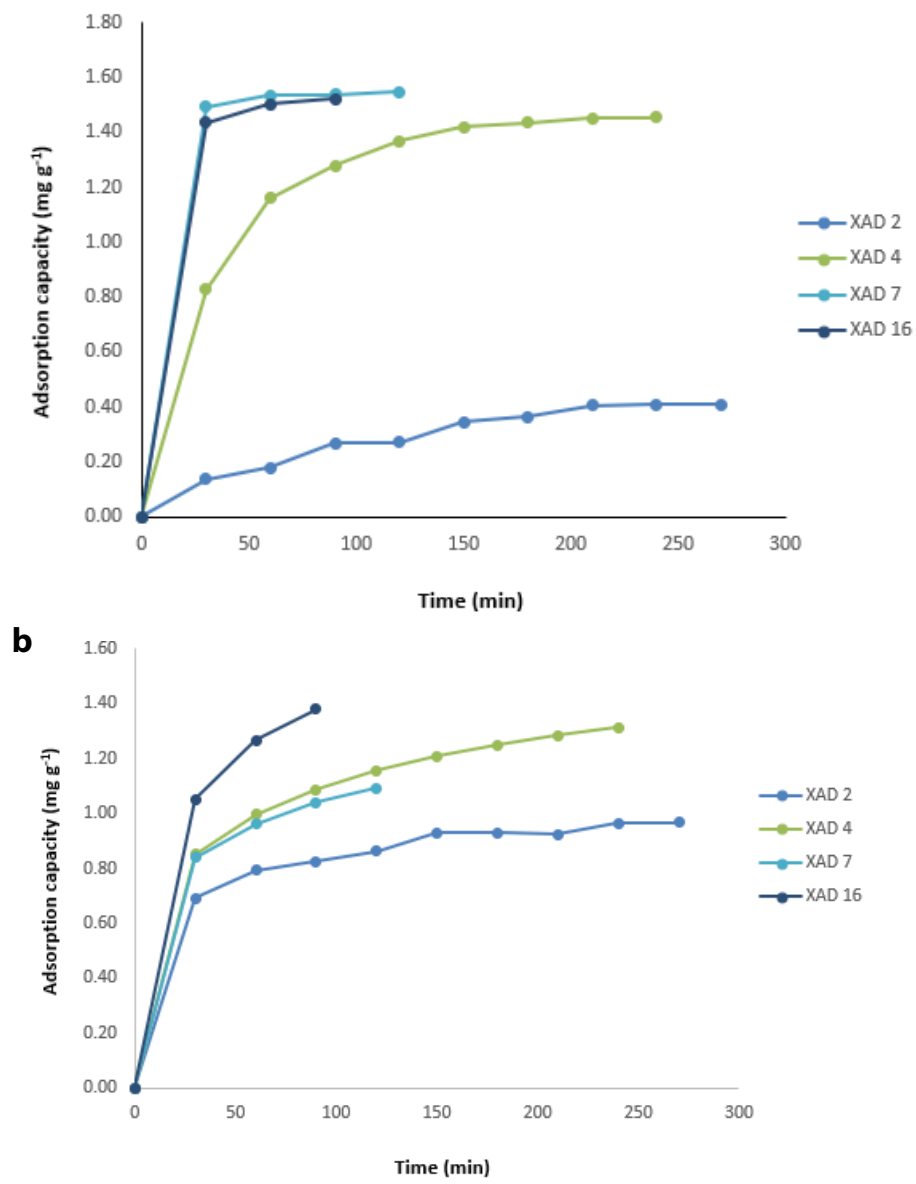

Figure 1. Determination of equilibrium time for CAM (a) and IBU (b) removal in terms of adsorption capacity 
isotherm models might be evaluated depending on the correlation coefficients $\left(R^{2}\right)$. However, it cannot be said that the experimental data obtained is compatible with a model, considering just $R^{2}$ value. Generally, constant of Langmuir model was calculated as negative for the IBU-resin systems. Therefore, the experimental data of the relevant system is not appropriate for the Langmuir isotherm. Depending on the Freundlich isotherm, the adsorption on the adsorbent surface is multilayer [20]. On the other hand, we can say that the obtained data is highly compatible with Freundlich equation by looking at the

Table 1. Kinetic parameters for the CAM and IBU adsorptions onto several macroporous resins

\begin{tabular}{|c|c|c|c|c|}
\hline Model & Adsorbate & Adsorbent & Parameter & Value \\
\hline \multirow{3}{*}{$\begin{array}{l}\text { Pseudo-First } \\
\text { Order }\end{array}$} & \multirow{6}{*}{ CAM } & XAD 4 & $\begin{array}{c}\mathrm{k}_{1}\left(\mathrm{~min}^{-1}\right) \\
\mathrm{q}_{\mathrm{e}}\left(\mathrm{mgg}^{-1}\right) \\
\mathrm{R}^{2}\end{array}$ & $\begin{array}{r}0,044 \\
1,368 \\
0,97\end{array}$ \\
\hline & & XAD 7 & $\begin{array}{l}\mathrm{k}_{1} \\
\mathrm{q}_{\mathrm{e}} \\
\mathrm{R}^{2}\end{array}$ & $\begin{array}{r}2,490 \\
1,373 \\
0,82\end{array}$ \\
\hline & & XAD 16 & $\begin{array}{l}\mathrm{k}_{1} \\
\mathrm{q}_{\mathrm{e}} \\
\mathrm{R}^{2}\end{array}$ & $\begin{array}{r}0,640 \\
1,310 \\
0,62\end{array}$ \\
\hline \multirow{3}{*}{$\begin{array}{l}\text { Pseudo-Second } \\
\text { Order }\end{array}$} & & XAD 4 & $\begin{array}{c}\mathrm{k}_{2}\left(\mathrm{mgg}^{-1} \min ^{-1}\right) \\
\mathrm{q}_{\mathrm{e}}\left(\mathrm{mgg}^{-1}\right) \\
\mathrm{R}^{2}\end{array}$ & $\begin{array}{r}0,011 \\
1,000 \\
0,99\end{array}$ \\
\hline & & XAD 7 & $\begin{array}{l}\mathrm{k}_{2} \\
\mathrm{q}_{\mathrm{e}} \\
\mathrm{R}^{2}\end{array}$ & $\begin{array}{r}0,079 \\
0,210 \\
0,99 \\
\end{array}$ \\
\hline & & XAD 16 & $\begin{array}{l}\mathrm{k}_{2} \\
\mathrm{q}_{\mathrm{e}} \\
\mathrm{R}^{2}\end{array}$ & $\begin{array}{r}0,066 \\
0,537 \\
0,99\end{array}$ \\
\hline \multirow{4}{*}{$\begin{array}{l}\text { Pseudo-First } \\
\text { Order }\end{array}$} & \multirow{8}{*}{ IBU } & XAD 2 & $\begin{array}{l}\mathrm{k}_{1} \\
\mathrm{q}_{\mathrm{e}} \\
\mathrm{R}^{2}\end{array}$ & $\begin{array}{r}0,024 \\
0,569 \\
0,93\end{array}$ \\
\hline & & XAD 4 & $\begin{array}{l}\mathrm{k}_{1} \\
\mathrm{q}_{\mathrm{e}} \\
\mathrm{R}^{2}\end{array}$ & $\begin{array}{r}0,024 \\
0,915 \\
0,93\end{array}$ \\
\hline & & XAD 7 & $\begin{array}{l}\mathrm{k}_{1} \\
\mathrm{q}_{\mathrm{e}} \\
\mathrm{R}^{2}\end{array}$ & $\begin{array}{c}0,008 \\
0,695 \\
0,90\end{array}$ \\
\hline & & XAD 16 & $\begin{array}{l}\mathrm{k}_{1} \\
\mathrm{q}_{\mathrm{e}} \\
\mathrm{R}^{2}\end{array}$ & $\begin{array}{r}0,046 \\
1,080 \\
0,93\end{array}$ \\
\hline \multirow{4}{*}{$\begin{array}{l}\text { Pseudo-Second } \\
\text { Order }\end{array}$} & & XAD 2 & $\begin{array}{c}\mathrm{k}_{2} \\
\mathrm{q}_{\mathrm{e}} \\
\mathrm{R}^{2}\end{array}$ & $\begin{array}{r}0,220 \\
1,008 \\
0,99\end{array}$ \\
\hline & & XAD 4 & $\begin{array}{l}\mathrm{k}_{2} \\
\mathrm{q}_{\mathrm{e}} \\
\mathrm{R}^{2}\end{array}$ & $\begin{array}{r}0,100 \\
1,278 \\
0,99\end{array}$ \\
\hline & & XAD 7 & $\begin{array}{l}\mathrm{k}_{2} \\
\mathrm{q}_{\mathrm{e}} \\
\mathrm{R}^{2}\end{array}$ & $\begin{array}{c}0,100 \\
1,152 \\
0,98\end{array}$ \\
\hline & & XAD 16 & $\begin{array}{l}\mathrm{k}_{2} \\
\mathrm{q}_{\mathrm{e}} \\
\mathrm{R}^{2}\end{array}$ & $\begin{array}{r}0,140 \\
1,479 \\
0,99\end{array}$ \\
\hline
\end{tabular}

Table 2. Isotherm models and equations

\begin{tabular}{|c|c|}
\hline Isotherm model & Equation \\
\hline Langmuir & $\frac{\mathrm{C}_{\mathrm{e}}}{\mathrm{q}_{\mathrm{e}}}=\frac{\mathrm{C}_{\mathrm{e}}}{\mathrm{q}_{\mathrm{m}}}+\frac{1}{\mathrm{~K}_{\mathrm{l}} \mathrm{q}_{\mathrm{m}}}$ \\
\hline Freundlich & $\log _{\mathrm{e}}=\log \mathrm{K}_{\mathrm{f}}+\frac{1}{\mathrm{n}} \log \mathrm{C}_{\mathrm{e}}$ \\
\hline
\end{tabular}

where $C_{e}=$ the equilibrium concentration of adsorbate $\left(\mathrm{mLL}^{-1}\right) \mathrm{q}_{\mathrm{e}}=$ the amount of rutine adsorbed per gram of the adsorbent at equilibrium $\left(\mathrm{mgg}^{-1}\right) \cdot \mathrm{q}_{\mathrm{c}}=$ maximum monolayer coverage capacity $\left(\mathrm{mgg}^{-1}\right) \mathrm{K}_{1}=$ Langmuir isotherm constant $\left(\mathrm{Lmg}^{-1}\right) . \mathrm{n}=$ adsorption intensity, $\mathrm{K}_{\mathrm{f}}=$ Freundlich isotherm constant $\left(\mathrm{mgg}^{-1}\right)$.
Table 3. Comparative results of the isotherm parameters

\begin{tabular}{|c|c|c|c|c|c|c|c|c|}
\hline & & \multirow[b]{2}{*}{ Temperature } & \multirow[b]{2}{*}{$\mathbf{q}_{\mathrm{m}}$} & \multicolumn{2}{|c|}{ Langmuir } & \multicolumn{3}{|c|}{ Freundlich } \\
\hline & & & & $\mathbf{K}_{1}$ & $\mathbf{R}^{2}$ & $\mathbf{K}_{\mathrm{f}}$ & $\mathbf{n}$ & $\mathbf{R}^{2}$ \\
\hline \multirow{12}{*}{ CAM } & \multirow{4}{*}{ XAD 4} & $293 \mathrm{~K}$ & 3,47 & 0,10 & 0,99 & 0,54 & 1,71 & 0,99 \\
\hline & & $298 \mathrm{~K}$ & 2,65 & 0,18 & 0,99 & 0,48 & 1,61 & 0,99 \\
\hline & & $303 \mathrm{~K}$ & 2,08 & 0,33 & 0,98 & 0,39 & 1,44 & 0,99 \\
\hline & & $308 \mathrm{~K}$ & 1,91 & 0,45 & 0,97 & 0,32 & 1,30 & 0,99 \\
\hline & \multirow{4}{*}{ XAD 7} & $293 \mathrm{~K}$ & 4,36 & 1,07 & 0,99 & 1,98 & 1,96 & 0,97 \\
\hline & & $298 \mathrm{~K}$ & 4,21 & 1,58 & 0,99 & 2,09 & 2,25 & 0,97 \\
\hline & & $303 \mathrm{~K}$ & 4,26 & 2,31 & 0,97 & 2,52 & 2,46 & 0,92 \\
\hline & & $308 \mathrm{~K}$ & 4,18 & 2,50 & 0,96 & 2,67 & 2,41 & 0,91 \\
\hline & \multirow{4}{*}{$\begin{array}{c}\text { XAD } \\
16\end{array}$} & $293 \mathrm{~K}$ & 6,02 & 0,15 & 0,96 & 1,96 & 2,10 & 0,95 \\
\hline & & $298 \mathrm{~K}$ & 4,58 & 0,31 & 0,95 & 2,25 & 2,04 & 0,94 \\
\hline & & $303 \mathrm{~K}$ & 3,35 & 1,14 & 0,92 & 2,46 & 1,53 & 0,93 \\
\hline & & $308 \mathrm{~K}$ & 3,34 & 1,59 & 0,91 & 2,41 & 1,33 & 0,92 \\
\hline \multirow{16}{*}{ IBU } & \multirow{4}{*}{ XAD 2} & $293 \mathrm{~K}$ & $-1,32$ & $-0,05$ & 0,98 & 0,088 & 0,80 & 0,93 \\
\hline & & $298 \mathrm{~K}$ & $-8,05$ & $-0,02$ & 0,96 & 0,017 & 0,52 & 0,88 \\
\hline & & $303 \mathrm{~K}$ & $-1,20$ & $-0,05$ & 0,99 & 0,016 & 0,52 & 0,96 \\
\hline & & $308 \mathrm{~K}$ & $-0,68$ & $-0,06$ & 0,96 & 0,006 & 0,41 & 0,99 \\
\hline & \multirow{4}{*}{ XAD 4} & $293 \mathrm{~K}$ & $-0,99$ & $-0,13$ & 0,97 & 0,64 & 0,75 & 0,87 \\
\hline & & $298 \mathrm{~K}$ & $-5,09$ & $-0,12$ & 0,98 & 0,04 & 0,41 & 0,94 \\
\hline & & $303 \mathrm{~K}$ & $-10,1$ & $-0,09$ & 0,99 & 0,45 & 0,55 & 0,98 \\
\hline & & $308 \mathrm{~K}$ & $-8,33$ & $-0,15$ & 0,99 & 0,66 & 0,79 & 0,99 \\
\hline & \multirow{4}{*}{ XAD 7} & $293 \mathrm{~K}$ & $-10,6$ & $-0,02$ & 0,99 & 0,89 & 0,19 & 0,99 \\
\hline & & $298 \mathrm{~K}$ & $-21,8$ & $-0,01$ & 0,98 & 0,90 & 0,23 & 0,99 \\
\hline & & $303 \mathrm{~K}$ & $-13,2$ & $-0,02$ & 0,99 & 0,89 & 0,26 & 0,99 \\
\hline & & $308 \mathrm{~K}$ & 14,6 & 0,03 & 0,99 & 1,05 & 0,40 & 0,97 \\
\hline & \multirow{4}{*}{$\begin{array}{c}\text { XAD } \\
16\end{array}$} & $293 \mathrm{~K}$ & $-10,7$ & $-0,05$ & 0,99 & 0,84 & 0,49 & 0,99 \\
\hline & & $298 \mathrm{~K}$ & 13,9 & 0,06 & 0,98 & 1,06 & 0,80 & 0,97 \\
\hline & & $303 \mathrm{~K}$ & 6,4 & 0,23 & 0,96 & 1,26 & 1,10 & 0,95 \\
\hline & & $308 \mathrm{~K}$ & 5,3 & 0,46 & 0,96 & 1,44 & 1,50 & 0,96 \\
\hline
\end{tabular}

system $\left(R^{2}>0.87\right)$. This indicates that the relevant adsorption processes represent a heterogeneous surface.

\section{Conclusion}

Adsorption of pharmaceutically active compounds (carmabazine and ibuprofen) has been accomplished with macroporous resins (XAD 2, 4, 7 and 16). Except for XAD 2, the tested resins showed successful performance to remove the selected compounds from their aqueous media. Approximately 87 to $99 \%$ of removal has been observed under the optimum adsorption conditions $(500 \mathrm{mg}$ of adsorbent for the adsorption of $30 \mathrm{mg} \mathrm{L}^{-1} \mathrm{CAM}$ and IBU solutions under $150 \mathrm{rpm}$ mixing speed of shaking bath at room temperature). Pseudo-first and second-order kinetic models were satisfactory to describe the experimental data for the adsorption of the selected pharmaceutically active compounds with high correlation coefficients. Generally, the equilibrium data were found to be in good agreement with Freundlich isotherm. On the other hand, CAM-resin systems have been fousnd to be exothermic depending on the parameters of the Lagmuir.

\section{Acknowledgement}

The authors thank the Research Fund of Istanbul UniversityCerrahpaşa for financial support for this research project (Project No: FBA-2018-30369).

\section{References}

1. Kerkez-Kuyumcu O, Bayazit SS, Salam MA (2016) Antibiotic amoxicillin removal from aqueous solution using magnetically modified graphene nanoplatelets. $J$ Ind Eng Chem 36: 198-205. 
2. Danalioglu ST, Bayazit SS, Kerkez Kuyumcu O, Salam MA (2017) Efficient removal of antibiotics by a novel magnetic adsorbent: Magnetic activated carbon/chitosan (MACC) nanocomposite. J Mol Liq 240: 589-596.

3. Halling-Sørensen B, Nors Nielsen S, Lanzky PF, Ingerslev F, Holten Lützhøft HC, et al. (1998) Occurrence, fate and effects of pharmaceutical substances in the environment- A review. Chemosphere 36: 357-393. [Crossref]

4. Mellah A, Fernandes SPS, Rodríguez R, Otero J, Paz J, et al. (2018) Adsorption of pharmaceutical pollutants from water using covalent organic frameworks, Chem A Eur J 24: 10601-10605.

5. Essandoh M, Kunwar B, Pittman CU, Mohan D, Mlsna T (2015) Sorptive removal of salicylic acid and ibuprofen from aqueous solutions using pine wood fast pyrolysis biochar. Chem Eng J 265: 219-227.

6. Suriyanon N, Punyapalakul P, Ngamcharussrivichai C (2013) Mechanistic study of diclofenac and carbamazepine adsorption on functionalized silica-based porous materials. Chem Eng J 214: 208-218

7. Soto ML, Moure A, Domínguez H, Parajó JC (2011) Recovery, concentration and purification of phenolic compounds by adsorption: A review. J Food Eng 105: 1-27.

8. Bui TX, Choi H (2010) Influence of ionic strength, anions, cations, and natural organic matter on the adsorption of pharmaceuticals to silica. Chemosphere 80: 681-686.

9. Khazri H, Ghorbel-Abid I, Kalfat R, Trabelsi-Ayadi M (2017) Removal of ibuprofen, naproxen and carbamazepine in aqueous solution onto natural clay: equilibrium, kinetics, and thermodynamic study, Appl Water Sci 7: 3031-3040.

10. Dickenson ER, Drewes JE (2010) Quantitative structure property relationships for the adsorption of pharmaceuticals onto activated carbon. Water Sci Technol 62: 2270-2276. [Crossref]
11. Bui TX, Choi H (2009) Adsorptive removal of selected pharmaceuticals by mesoporous silica SBA-15. J Hazard Mater 168: 602-608. [Crossref]

12. Bui TX, Pham VH, Le ST, Choi H (2013) Adsorption of pharmaceuticals onto trimethylsilylated mesoporous SBA-15. J Hazard Mater 254-255: 345-353. [Crossref]

13. Scheytt T, Mersmann P, Lindstädt R, Heberer T (2005) Determination of sorption coefficients of pharmaceutically active substances carbamazepine, diclofenac, and ibuprofen, in sandy sediments. Chemosphere 60: 245-253. [Crossref]

14. Zhao H, Liu X, Cao Z, Zhan Y, Shi X, et al. (2016) Adsorption behavior and mechanism of chloramphenicols, sulfonamides, and non-antibiotic pharmaceuticals on multiwalled carbon nanotubes, J Hazard Mater 310: 235-245.

15. Sahin S, Bilgin M (2017) Selective adsorption of oleuropein from olive (Olea europaea) leaf extract using macroporous resin. Chem Eng Commun 204: 1391-1400.

16. Sahin S, Elhussein EAA, Bilgin M, Kurtulbas E, Bayazit SS (2018) Investigation of extractive interaction between ionic liquids and carbamazepine. J Mol Liq 268: 523528

17. Zhou Z, iang JQ (2012) Detection of ibuprofen and ciprofloxacin by solid-phase extraction and UV/Vis spectroscopy. J Appl Spectrosc 79: 459-464.

18. Subramanyam B, Das A (2009) Study of the adsorption of phenol by two soils based on kinetic and isotherm modeling analyses. Desalination 249: 914-921.

19. Ho Y, McKay G (1999) Pseudo-second order model for sorption processes. Process Biochem 34: 451-465.

20. Emik S (2014) Preparation and characterization of an IPN type chelating resin containing amino and carboxyl groups for removal of $\mathrm{Cu}$ (II) from aqueous solutions. React Funct Polym 75: 63-74.

Copyright: (C2019 Özçelik G. This is an open-access article distributed under the terms of the Creative Commons Attribution License, which permits unrestricted use, distribution, and reproduction in any medium, provided the original author and source are credited. 